\title{
Plant growth and phosphorus uptake in mycorrhizal rangpur lime seedlings under different levels of phosphorus
}

\author{
Marco Antonio Nogueira(1) and Elke Jurandy Bran Nogueira Cardoso ${ }^{(2)}$
}

\begin{abstract}
(1)Universidade Estadual de Londrina, Centro de Ciências Biológicas, Dep. de Microbiologia, Caixa Postal 6001, CEP $86051-990$ Londrina, PR. E-mail: nogueira@uel.br (2)Escola Superior de Agricultura Luiz de Queiroz, Dep. de Solos e Nutrição de Plantas, Caixa Postal 09, CEP 13418-900 Piracicaba, SP. E-mail: ejbncard@esalq.usp.br
\end{abstract}

\begin{abstract}
The objective of this work was to evaluate the response of rangpur lime (Citrus limonia) to arbuscular mycorrhiza (Glomus intraradices), under P levels ranging from low to excessive. Plants were grown in three levels of soluble P (25, 200 and 1,000 mg kg-1), either inoculated with Glomus intraradices or left noninoculated, evaluated at 30, 60, 90, 120 and 150 days after transplanting (DAT). Total dry weight, shoot P concentration and specific P uptake by roots increased in mycorrhizal plants with the doses of 25 and $200 \mathrm{mg} \mathrm{kg}^{-1} \mathrm{P}$ at 90 DAT. With $1,000 \mathrm{mg} \mathrm{kg}^{-1} \mathrm{P}$, mycorrhizal plants had a transient growth depression at 90 and 120 DAT, and nonmycorrhizal effects on P uptake at any harvesting period. Root colonization and total external mycelium correlated positively with shoot P concentration and total dry weight at the two lowest P levels. Although the highest P level decreased root colonization, it did not affect total external mycelium to the same extent. As a result, a P availability imbalance affected negatively the mycorrhizal symbiosis and, consequently, the plant growth.
\end{abstract}

Index terms: Citrus, Glomus, active external mycelium, growth depression, rootstock, total external mycelium.

\section{Crescimento e absorção de fósforo por plântulas de limão 'Cravo' micorrizadas sob diferentes níveis de fósforo}

\begin{abstract}
Resumo - O objetivo deste trabalho foi avaliar a resposta do limão ‘Cravo' (Citrus limonia) à micorriza arbuscular (Glomus intraradices), com variações de níveis de P de baixo a excessivo. As plantas foram cultivadas em três níveis de P solúvel (25, 200 e $1.000 \mathrm{mg} \mathrm{kg}^{-1}$ ), com inoculação de Glomus intraradices ou sem inoculação, e avaliadas aos 30, 60, 90, 120 e 150 dias depois do transplantio (DAT). A biomassa seca total, a concentração de P na parte aérea, e a absorção específica de P pelas raízes aumentaram nas plantas micorrizadas nas doses de 25 e $200 \mathrm{mg} \mathrm{kg}^{-1}$ de P aos 90 DAT. Na dose de $1.000 \mathrm{mg} \mathrm{kg}^{-1}$ de P, houve depressão transiente de crescimento nas plantas micorrizadas, aos 90 e 120 DAT, e não houve efeito micorrízico sobre a absorção de P em qualquer época de colheita. A colonização radicular e o micélio externo total correlacionaram-se positivamente com a concentração de P na parte aérea e biomassa seca total, nos dois menores níveis de P. Embora o maior nível de P tenha causado redução da colonização radicular, isto não afetou o micélio externo total na mesma extensão. Como resultado, um desequilíbrio na disponibilidade de $\mathrm{P}$ afetou negativamente a simbiose micorrízica e, conseqüentemente, o crescimento da planta.
\end{abstract}

Termos para indexação: Citrus limonia, Glomus intraradices, micélio externo ativo, depressão de crescimento, porta-enxerto, micélio externo total.

\section{Introduction}

Rangpur lime (Citrus limonia L. Osbeck) is widely used as rootstock in commercial orchards in Brazil. These plants have a coarse root system, and as a result, they are more dependent on arbuscular mycorrhizal fungi (AMF) for nutrient uptake, mainly those with low mobility in the soil, like P, Zn and Cu (Marschner \& Dell, 1994).

The AMF growth occurs inside the roots and also outside as external mycelium. Nevertheless, the latter has received less attention than the first (Miranda \& Harris, 1994). There are evidences that plant response to mycorrhiza cannot be explained solely by the internal colonization. The beneficial effect of mycorrhiza is mainly attributed to the fungal hyphae spreading up to $11 \mathrm{~cm}$ through the soil beyond the rhizosphere, which enables more efficient soil exploitation for nutrients (Li et al., 1991), being responsible for up to $80 \%$ of the $\mathrm{P}$ and $60 \%$ of the $\mathrm{Cu}$ uptaken by plant (Marschner \& Dell, 1994). 
Phosphorus availability affects the interaction between AMF and plants. It is well known that under excessive soil $\mathrm{P}$, internal root colonization decreases, but little is known about the effects on the external mycelium (EM). Some results point towards a positive correlation between total EM and P availability (Cardoso-Filho et al., 1999; Melloni \& Cardoso, 1999b; Melloni et al., 2000), others state the opposite (Miranda \& Harris, 1994; Nogueira \& Cardoso, 2000). Citrus dependence on AMF decreases as $\mathrm{P}$ availability increases and, in some cases, high $\mathrm{P}$ availability may result in plant growth depression (Peng et al., 1993; Graham et al., 1997; Melloni \& Cardoso, 1999b). The generally accepted hypothesis to explain this negative effect is the endophyte action, as C sink on the host (Graham et al., 1997; Jifon et al., 2002). Indeed, the relative development of the internal and the external mycelium should be in balance, to promote a positive growth response (Abbott et al., 1984).

The objective of this work was to evaluate the response of rangpur lime (Citrus limonia) to arbuscular mycorrhiza (Glomus intraradices), under P levels ranging from low to excessive.

\section{Material and Methods}

The experiment was completely randomized, in a 2x3 factorial arrangement, with five replications. The first factor was AMF, i.e., plants inoculated (+AMF) or noninoculated (-AMF) with Glomus intraradices (Schenck \& Smith), and the second factor was phosphate levels added in the substrate $\left(25,200\right.$ or $1,000 \mathrm{mg} \mathrm{kg}^{-1} \mathrm{P}$ as triple superphosphate). Plants were harvested every 30 days up to 150 days after transplanting (DAT). Harvest time was not analyzed as a factor.

The substrate was a soil:sand mixture [three parts of a top $(0-20 \mathrm{~cm})$ sandy soil (Typic Quartzipsamments) and one of washed sand], in order to obtain a non-Pfixing substrate, and to allow for an easy extraction of the external mycelium (EM). The mixture was autoclaved $\left(121^{\circ} \mathrm{C}\right.$ for two hours), for elimination of all native AMF inocula. Dolomitic limestone (440 $\mathrm{g} \mathrm{kg}^{-1}$ $\mathrm{CaO}$ and $250 \mathrm{~g} \mathrm{~kg}^{-1} \mathrm{MgO}$ ) was added at a rate of $1.62 \mathrm{~g} \mathrm{~kg}^{-1}$ of substrate to raise the $\mathrm{pH}\left(\mathrm{CaCl}_{2} 0.01 \mathrm{M}\right)$ to 6 , previously tested by incubation methods. Afterwards, the chemical composition of the substrate was: organic matter, $14 \mathrm{~g} \mathrm{dm}^{-3}$; $\mathrm{P}, 2 \mathrm{mg} \mathrm{dm}^{-3}$; and, in $\mathrm{mmol}_{\mathrm{C}} \mathrm{dm}^{-3}, \mathrm{~K}, 0.5$; Ca, 9; and $\mathrm{Mg}, 7$. Ground triple superphosphate fertilizer $(<0.25 \mathrm{~mm})$ was added
(P, $80.8 \mathrm{~g} \mathrm{~kg}^{-1}$; Ca, $185.7 \mathrm{~g} \mathrm{~kg}^{-1}$ and $\mathrm{S}, 116 \mathrm{~g} \mathrm{~kg}^{-1}$ ) to provide 25, 200 or $1,000 \mathrm{mg} \mathrm{kg}^{-1} \mathrm{P}$ in the substrate. Additional fertilizer was added in all pots, amounting to: $\mathrm{N}, 80 \mathrm{mg}\left(\mathrm{NH}_{4} \mathrm{NO}_{3}\right) ; \mathrm{K}, 150 \mathrm{mg}\left(\mathrm{K}_{2} \mathrm{SO}_{4}\right) ; \mathrm{Zn}, 2 \mathrm{mg}$ $\left(\mathrm{ZnSO}_{4} .7 \mathrm{H}_{2} \mathrm{O}\right)$ and $\mathrm{B}, 0.5 \mathrm{mg}\left(\mathrm{H}_{3} \mathrm{BO}_{3}\right)$ per $\mathrm{kg}$ of substrate. Nitrogen, $40 \mathrm{mg} \mathrm{kg}^{-1}$ as $\left(\mathrm{NH}_{4}\right)_{2} \mathrm{SO}_{4}$, was again applied at 30, 60 and 90 DAT.

Rangpur lime seeds were surface-sterilized with hipochlorite solution $\left(20 \mathrm{~mL} \mathrm{~L}^{-1}\right)$ for five minutes, and germinated for one month in autoclaved sand. As citrus grows slowly and does not require large rooting volumes at the early stages, smaller pots $\left(1.5 \mathrm{dm}^{3}\right)$ were used for plants harvested at 30 and 60 DAT; intermediate ones $\left(4 \mathrm{dm}^{3}\right)$ for plants harvested at 90 and 120 DAT; and, finally, larger ones $\left(8 \mathrm{dm}^{3}\right)$ for plants harvested at 150 DAT. Seedlings were selected for uniformity and transplanted to the pots containing 1.6, 3.8 or $8.0 \mathrm{~kg}$ of substrate, according to their capacity. The AMF inoculum consisted of 10, 20 or $30 \mathrm{~g}$ of substrate (used to inoculate either 1.6, 3.8 or $8.0 \mathrm{~kg}$ pots, respectively), in which G. intraradices had been multiplied on Brachiaria decumbens. The inoculum, containing infected root segments with hyphae and spores, was placed about $5 \mathrm{~cm}$ below the surface in the +AMF pots. The -AMF pots received the same amount of a substrate in which Brachiaria decumbens had been grown without G. intraradices.

Plants grew in a greenhouse with temperature and relative humidity varying in a range of 34 to $12^{\circ} \mathrm{C}$, and 50 to $95 \%$, respectively. Day length varied from 13 to 16 hours, and the photosynthetic photon flux density averaged $900 \mu \mathrm{mol} \mathrm{m}^{-2} \mathrm{~s}^{-1}$, at noon on sunny days, and $400 \mu \mathrm{mol} \mathrm{m}{ }^{-2} \mathrm{~s}^{-1}$ on cloudy days. Plants were irrigated daily with distilled water.

Shoots and roots were collected, at each harvest, washed in tap water, distilled water and weighed. A root sample was kept in a fixing solution (ethanol, $2 \mathrm{~L}$; formaldehyde, $0.5 \mathrm{~L}$; acetic acid $0.1 \mathrm{~L}$; distilled water, $4 \mathrm{~L}$ ), prior to clearing and staining (Phillips \& Hayman, 1970). Mycorrhizal colonization, expressed in percentage of root length, was evaluated in five microscopic slides containing ten pieces of 1-cm long root under 100x magnification (Giovannetti \& Mosse, 1980). The remainder of the root and the shoot were oven-dried to constant weight $\left(70^{\circ} \mathrm{C}\right.$ for 72 hours). Dried shoot and root, when enough, were ground in a Wiley mill, digested in nitric-perchloric acid and the $\mathrm{P}$ concentration was determined colorimetrically (Murphy \& Riley, 1962). 
Substrate was collected to extract and estimate the total EM and active EM (Schubert et al., 1987; Sylvia, 1988; Melloni \& Cardoso, 1999a). Ten-gram-samples were added to $1,500 \mathrm{~mL}$ of tap water in bursts, and passed afterwards through a 0.71 and $0.25 \mathrm{~mm}$ screen sieve to remove bulk debris. The effluent was homogenized in a blender for two minutes, and the sand was allowed to settle for 30 seconds. Then, the uppermost $500 \mathrm{~mL}$ were passed through a $44 \mu \mathrm{m}$ screen sieve, where the hyphal mass was retained and transferred into a $10 \mathrm{~mL}$ graduated cylinder containing phosphate buffer ( $\mathrm{pH}$ 7.3). Subsamples containing $5 \mathrm{~mL}$ were incubated with Fluorescein Diacetate (FDA) solution, and the mycelium was retained by filtration on a 3-mm squared cellulose membrane with $0.45 \mu \mathrm{m}$ pores (Sartorius). The membranes were evaluated in 64 fields for active EM, under an epifluorescence microscope (Olympus BX40, 100x magnification) equipped with an eyepiece Whipple disc with 10x10 lined grid. Active EM becomes bright-green under UV light, after FDA is hydrolyzed to fluorescein and acetate, by esterases in the active mycelium (Schubert et al., 1987). A second evaluation was performed on the same sample, but under white light, in order to assess the total external mycelium. It is quite difficult to differentiate AMF hyphae from other filamentous fungi in the soil (Abbott et al., 1984), under microscope, unless they are attached to their spores and more accurate examinations are made. In addition, a mycorrhizal rizosphere is quantitatively and qualitatively different from a nonmycorrhizal one, with regard to soil microorganisms (Linderman, 1992). For this reason, results for EM (total and active) were presented without subtracting the values found in the -AMF corresponding control.

The specific $\mathrm{P}$ uptake was calculated by the ratio between total $\mathrm{P}$ in the shoot per gram of dry root. For this calculation, $P$ concentration in the roots could not be considered, because the weight of individual plant was too low to allow for chemical analysis.

Results from each harvest were separately submitted to the analysis of variance (ANOVA test), using the general linear models procedure (SAS Institute, 1996). Student $t$ test $(\mathrm{p}<0.05)$ was applied to compare + AMF and -AMF treatments at each $\mathrm{P}$ level. Correlation analyses were obtained by means of Pearson's correlation coefficient and its significance level $(\mathrm{p}>|\mathrm{R}|)$.

\section{Results and Discussion}

The +AMF plants showed greater total dry biomass at 25 and $200 \mathrm{mg} \mathrm{kg}^{-1} \mathrm{P}$ concentrations from 90 DAT onwards, probably when the symbiosis became functional (Table 1). However, at $1,000 \mathrm{mg} \mathrm{kg}^{-1} \mathrm{P}$, +AMF plants had a transitory growth depression of 23 and $18 \%$ at 90 and 120 DAT, respectively. Growth increase in + AMF plants under limiting $\mathrm{P}$ availability has been reported as the most common effects of AMF (Melloni \& Cardoso, 1999b; Graham, 2000; Melloni et al., 2000), but less common is the plant growth depression under high $\mathrm{P}$ supply (Graham, 2000; Nogueira \& Cardoso, 2000; Jifon et al., 2002). Under high P availability, AMF infection may become a C sink (Graham et al., 1997), which carries the host to a growth depression in relation to -AMF plants. According to Peng et al. (1993), C expended by mycorrhizal roots was $37 \%$ higher than nonmycorrhizal ones, but total plant dry weight reduction was only $8 \%$. The relative costs of mycorrhizal colonization may change with plant's ontogeny and the stage of mycorrhizal colonization (Graham, 2000). In fact, +AMF plants overtook -AMF ones in $21 \%$ at 150 DAT. A transient growth depression followed by a growth increase was observed earlier in mycorrhizal soybean (Bethlenfalvay et al., 1982; Nogueira \& Cardoso, 2000), but not in citrus.

Table 1. Total dry weight (g) and mycorrhizal effectiveness (ME\%) every 30 days after transplanting (DAT), of mycorrhizal (+AMF) and nonmycorrhizal (-AMF) Citrus limonia grown with 25, 200 or 1,000 $\mathrm{mg} \mathrm{kg}^{-1} \mathrm{P}$.

\begin{tabular}{|c|c|c|c|c|c|c|c|c|c|}
\hline \multirow[t]{3}{*}{ DAT } & \multicolumn{9}{|c|}{$\mathrm{P}\left(\mathrm{mg} \mathrm{kg}^{-1}\right)$} \\
\hline & \multicolumn{3}{|c|}{25} & \multicolumn{3}{|c|}{200} & \multicolumn{3}{|c|}{1,000} \\
\hline & $+\mathrm{AMF}$ & -AMF & $\mathrm{ME} \%{ }^{(1)}$ & $+\mathrm{AMF}$ & -AMF & ME\% ${ }^{(1)}$ & $+\mathrm{AMF}$ & -AMF & ME\% $\%^{(1)}$ \\
\hline 30 & $0.127^{\mathrm{ns}}$ & 0.118 & +8 & $0.130^{\mathrm{ns}}$ & 0.128 & +2 & $0.122^{\mathrm{ns}}$ & 0.121 & +1 \\
\hline 60 & $0.218^{\mathrm{ns}}$ & 0.209 & +4 & $0.314^{\mathrm{ns}}$ & 0.228 & +38 & $0.534^{\mathrm{ns}}$ & 0.473 & +13 \\
\hline 90 & $0.392^{*}$ & 0.206 & +90 & $0.914^{*}$ & 0.356 & +157 & $1.306^{*}$ & 1.707 & -23 \\
\hline 20 & $1.580^{*}$ & 0.224 & +605 & $2.011^{*}$ & 0.865 & +132 & $3.862^{*}$ & 4.716 & -18 \\
\hline 50 & $2.249^{*}$ & 0.245 & +818 & $4.354^{*}$ & 1.704 & +155 & $9.886^{*}$ & 8.187 & +21 \\
\hline
\end{tabular}

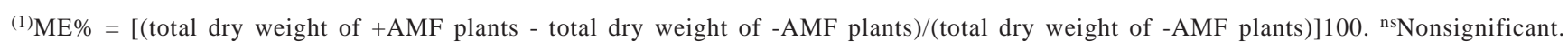

*Significant at $\mathrm{p} \leq 0.05$ (Student's $\mathrm{t}$ test). 
Root colonization increased up to 90 DAT in the treatments with 25 and $200 \mathrm{mg} \mathrm{kg}^{-1} \mathrm{P}$ (Figure 1), and this may have positively influenced the plant growth. In both cases, root colonization reached a maximum between 90 and 120 DAT, and decreased at 150 DAT; nevertheless, root colonization was inhibited at $1,000 \mathrm{mg} \mathrm{kg}^{-1} \mathrm{P}$, generally below $8 \%$. This colonization level, in spite of low, resulted in plant growth depression as discussed previously. No colonization was observed in -AMF plants.

Conversely to the negative effect of the highest $\mathrm{P}$ level on root colonization, this result was not observed on the external mycelium (Figure 2). Total EM and active EM always had higher figures in the substrate with +AMF plants, at all P levels, along the experiment. Although some authors (Abbott et al., 1984; Sylvia, 1988; Li et al., 1991) suggested the subtraction of the mycelium estimated in -AMF treatments from their respective +AMF counterparts, both data were presented, because it is quite difficult to distinguish mycorrhizal mycelium from that from other filamentous fungi (Sylvia, 1988; Kabir et al., 1996; Nogueira \& Cardoso, 2000). In addition, interactions between AMF and saprophytic fungi are unknown, whether stimulating or inhibiting each other. The total EM increased with time and reached about $19 \mathrm{~m} \mathrm{~g}^{-1}$ in the substrate with +AMF plants at 90 DAT, in all P levels. These data are in agreement with previous works (Abbott et al., 1984; Schubert et al., 1987; Sylvia, 1988; Li et al., 1991), in which the total EM ranged from less than 1 to about $26 \mathrm{~m} \mathrm{~g}^{-1}$.

Soil available $\mathrm{P}$ affects the mycorrhizal EM during the early stages of root colonization, when the primary

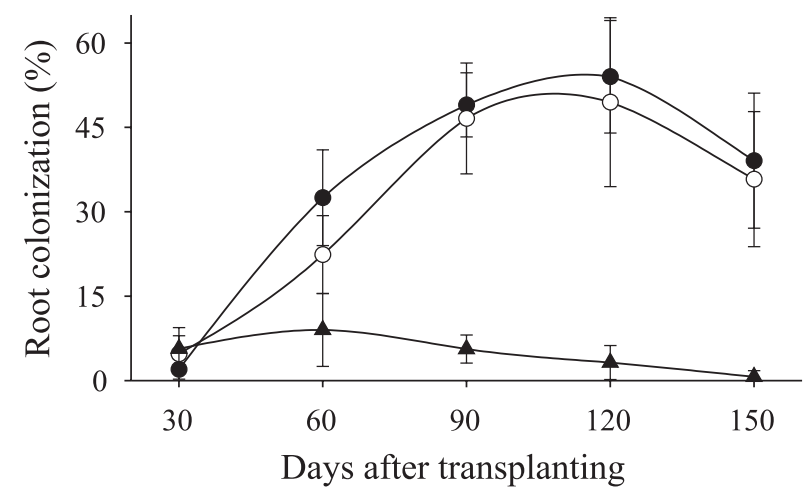

Figure 1. Root colonization of Citrus limonia by Glomus intraradices every 30 days after transplanting, grown with

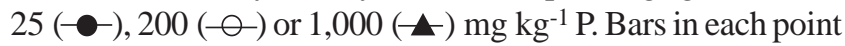
represents means \pm standard error. infection units are established (Miranda \& Harris, 1994). Indeed, at 30 DAT, the highest $P$ level reduced total and active EM in the +AMF treatments, compared to the lowest P level. Nevertheless, total EM reached similar values, at all P levels, from 60 DAT onwards, although percentage of root colonization had remained low at the highest $\mathrm{P}$ level. A decrease in root colonization and an increase in total EM, in all P levels, would suggest that the mycorrhizal EM is not sensitive to high soil P levels, in later stages of development, although the internal phase remains strongly affected. This imbalance between the internal and external mycelia has been pointed out as one of the reasons for plant growth depression (Bethlenfalvay et al., 1982), as observed at 90 and 120 DAT.

There was close correlation between root colonization and total EM, corroborating previous findings (Kabir et al., 1996), according to harvesting time (Table 2) and $\mathrm{P}$ levels (Table 3), except at $1,000 \mathrm{mg} \mathrm{kg}^{-1} \mathrm{P}$. Total EM

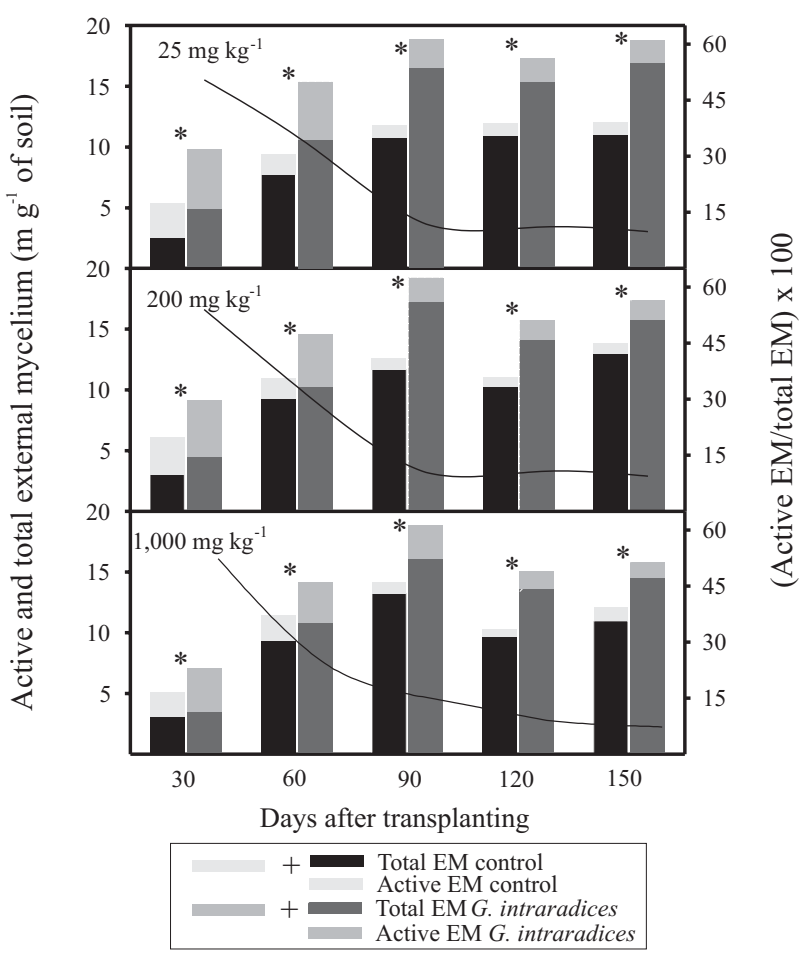

Figure 2. Total external mycelium (total EM), active external mycelium (active EM) and total EM/active EM ratio every 30 days after transplanting of: +AMF (Glomus intraradices) and -AMF (Control) Citrus limonia grown with 25, 200 or $1,000 \mathrm{mg} \mathrm{kg}^{-1} \mathrm{P}$. Means marked by $(*)$, at each $\mathrm{P}$ level and harvest, differ between -AMF and + AMF treatments for active and total EM at $\mathrm{p} \leq 0.05$ (Student's $\mathrm{t}$ test). 
correlated more strongly to active EM in the earlier harvests. Correlations between root colonization and total and active EM were always positive at every harvesting time. When the correlation was considered for each $\mathrm{P}$ level, there were opposite responses in the correlations between root colonization and total and active EM. While total EM correlated positively with root colonization at the two lowest P levels, active EM correlated negatively. At the highest P level, this relationship was inverted. These observations strengthen the role of soil $P$ availability on the balance between the internal and external phases of mycorrhizal symbiosis (Bethlenfalvay et al., 1982; Miranda \& Harris, 1994).

Active EM decreased with time as a proportion of the total EM. At 30 DAT it was about 50\% and decreased to $8 \%$ at $150 \mathrm{DAT}$, as reported previously (Schubert et al., 1987; Sylvia, 1988; Cardoso-Filho et al., 1999). As $\mathrm{P}$ uptake from soil, by fungal hyphae, is an active mechanism, a reduction of active EM would have a negative effect on P uptake (Sylvia, 1988). Nevertheless, total EM increased and this was also able to translocate P (Schubert et al., 1987). In fact, there was no significant correlation between active EM and P concentrations in the shoot, but there were positive correlations between total EM and shoot P concentration, at P levels of 25 and $200 \mathrm{mg} \mathrm{kg}^{-1}$ (Table 3). In addition, root colonization correlated positively with shoot $\mathrm{P}$ concentration, at $\mathrm{P}$ levels of 25 and $200 \mathrm{mg} \mathrm{kg}^{-1}$, and there was no correlation at $1,000 \mathrm{mg} \mathrm{kg}^{-1}$. As a result, there was positive correlation between total dry weight and root colonization, at the two lowest P levels and negative correlation at

Table 2. Pearson's correlation coefficient (R) and significance level $(\mathrm{p}>|\mathrm{R}|)$ every 30 days after transplanting (DAT), between total external mycelium, active external mycelium and mycorrhizal colonization (\%) of Citrus limonia(1).

\begin{tabular}{clcclcc}
\hline DAT & \multirow{2}{*}{$\begin{array}{c}\text { External } \\
\text { mycelium }\end{array}$} & \multicolumn{2}{c}{$\begin{array}{c}\text { Total external } \\
\text { mycelium }\end{array}$} & & \multicolumn{2}{c}{$\begin{array}{c}\text { Mycorrhizal } \\
\text { colonization }\end{array}$} \\
\cline { 3 - 4 } & & $\mathrm{R}$ & $\mathrm{p}>|\mathrm{R}|$ & & $\mathrm{R}$ & $\mathrm{p}>|\mathrm{R}|$ \\
\hline \multirow{2}{*}{30} & Active & 0.98 & 0.0001 & & 0.57 & 0.156 \\
& Total & - & - & & 0.57 & 0.278 \\
\hline \multirow{2}{*}{60} & Active & 0.96 & 0.024 & & 0.97 & 0.001 \\
& Total & - & - & & 0.88 & 0.020 \\
\hline \multirow{2}{*}{90} & Active & 0.63 & 0.015 & & 0.40 & 0.030 \\
& Total & - & - & & 0.55 & 0.001 \\
\hline 120 & Active & 0.64 & 0.035 & & 0.77 & 0.005 \\
& Total & - & - & & 0.57 & 0.068 \\
\hline 150 & Active & 0.36 & 0.076 & & 0.42 & 0.037 \\
& Total & - & - & & 0.60 & 0.001 \\
\hline
\end{tabular}

${ }^{(1)} \mathrm{n}=30$. the highest, in a similar way for total EM. In addition, $\mathrm{P}$ levels changed the correlations between root colonization and active EM, and root colonization and total EM. These findings reinforce the role of AMF in plant growth depression under high soil $P$ availability.

At P supplies of 25 and $200 \mathrm{mg} \mathrm{kg}^{-1}$, from 90 DAT onwards, +AMF plants had greater $\mathrm{P}$ concentrations in relation to -AMF plants (Figure 3), concomitantly to the specific $P$ uptake rate (Figure 4). At the $1,000 \mathrm{mg} \mathrm{kg}^{-1}$ $\mathrm{P}$ supply, both +AMF and -AMF plants had the same pattern of $\mathrm{P}$ uptake and shoot $\mathrm{P}$ concentrations. It is notorious that mycorrhizal citrus have higher $\mathrm{P}$ concentrations than control plants (Peng et al., 1993; Melloni et al., 2000) but, in this case, only at 25 and $200 \mathrm{mg} \mathrm{kg}^{-1} \mathrm{P}$. In these cases, shoot P concentrations in + AMF plants were above the sufficiency level of $1.9 \mathrm{~g} \mathrm{~kg}^{-1}$ for citrus, whereas the -AMF plants remained below the deficiency level of $1 \mathrm{~g} \mathrm{~kg}^{-1}$ (Graham et al., 1997). The EM may be responsible for more than $75 \%$ of the plant P uptake (Li et al., 1991). Based on the specific $P$ uptake rate it could be seen that similar values were achieved by roots of +AMF plants, at the two lowest $\mathrm{P}$ levels. Under nonexcessive $\mathrm{P}$ availability, the mycorrhiza was more effective in $\mathrm{P}$ uptake than roots alone. AMF did not contribute to P uptake under excessive $\mathrm{P}$, and $+\mathrm{AMF}$ and -AMF plants had the same $P$ concentrations. In this case, plants did not benefit from AMF with regard to $P$ uptake, since $P$ availability was sufficient for independent root system absorption. Data

Table 3. Pearson's correlation coefficient (R) and significance level ( $\mathrm{p}>|\mathrm{R}|)$ between mycorrhizal colonization (COL), total external mycelium (Total EM), active external mycelium (Active EM), shoot P concentration (Shoot P) and total plant dry weight (TDW), according to P levels ${ }^{(1)}$.

\begin{tabular}{|c|c|c|c|c|c|c|c|}
\hline \multirow{2}{*}{$\begin{array}{c}\mathrm{P} \\
\left(\mathrm{mg} \mathrm{kg}^{-1}\right)\end{array}$} & \multirow[t]{2}{*}{ Variable } & \multicolumn{2}{|c|}{$\mathrm{COL}$} & \multicolumn{2}{|c|}{ Total EM } & \multicolumn{2}{|c|}{ Active EM } \\
\hline & & $\mathrm{R}$ & $\mathrm{p}>|\mathrm{R}|$ & $\mathrm{R}$ & $\mathrm{p}>|\mathrm{R}|$ & $\mathrm{R}$ & $\mathrm{p}>|\mathrm{R}|$ \\
\hline \multirow[t]{4}{*}{25} & TDW & 0.59 & 0.001 & 0.41 & 0.002 & -0.39 & 0.036 \\
\hline & Shoot P & 0.83 & 0.005 & 0.66 & 0.055 & 0.02 & 0.975 \\
\hline & $\mathrm{COL}$ & - & - & 0.69 & 0.001 & -0.48 & 0.011 \\
\hline & Total EM & - & - & - & . & -0.69 & 0.001 \\
\hline \multirow[t]{4}{*}{200} & TDW & 0.54 & 0.001 & 0.50 & 0.001 & -0.47 & 0.009 \\
\hline & Shoot P & 0.73 & 0.001 & 0.54 & 0.010 & 0.13 & 0.550 \\
\hline & $\mathrm{COL}$ & - & - & 0.67 & 0.001 & -0.38 & 0.048 \\
\hline & Total EM & - & - & - & - & -0.59 & 0.001 \\
\hline \multirow[t]{4}{*}{1,000} & TDW & -0.57 & 0.001 & 0.27 & 0.154 & -0.73 & 0.001 \\
\hline & Shoot P & -0.10 & 0.563 & 0.11 & 0.540 & 0.31 & 0.095 \\
\hline & COL & - & - & -0.24 & 0.224 & 0.54 & 0.001 \\
\hline & Total EM & - & - & - & - & -0.37 & 0.041 \\
\hline
\end{tabular}

(1) $\mathrm{n}=50$. 


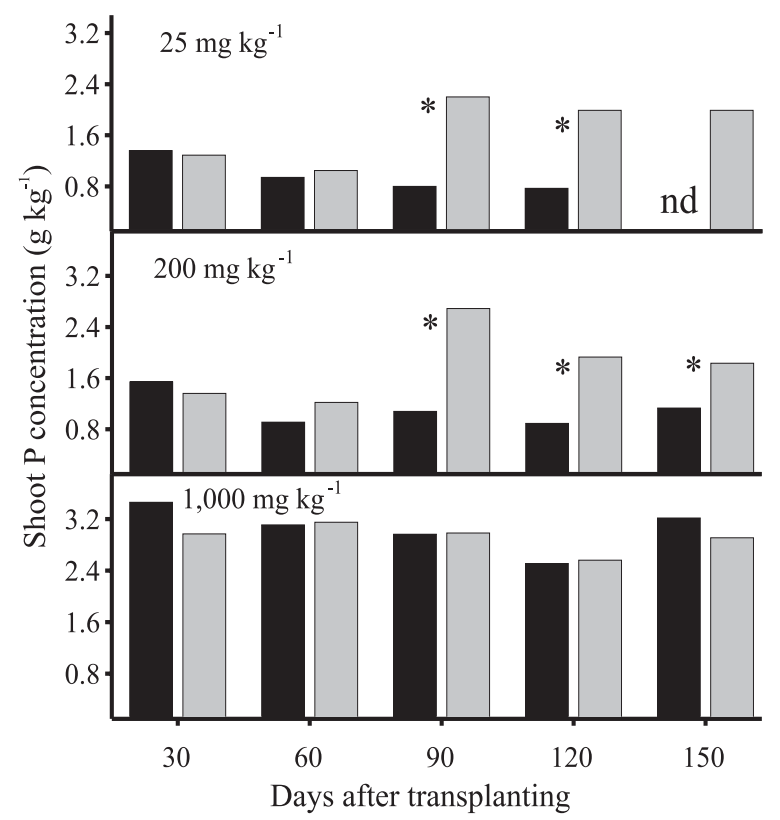

Figure 3. Shoot $\mathrm{P}$ concentration, every 30 days after transplanting of +AMF (Glomus intraradices, $\square$ ) and -AMF (Control, Citrus limonia, grown with 25, 200 or $1,000 \mathrm{mg} \mathrm{kg}^{-1} \mathrm{P}$. Means marked by $\left({ }^{*}\right)$, at each $\mathrm{P}$ level and harvest, differ between -AMF and +AMF treatments at $\mathrm{p} \leq 0.05$ (Student's $\mathrm{t}$ test). $\mathrm{nd}=$ not determined.

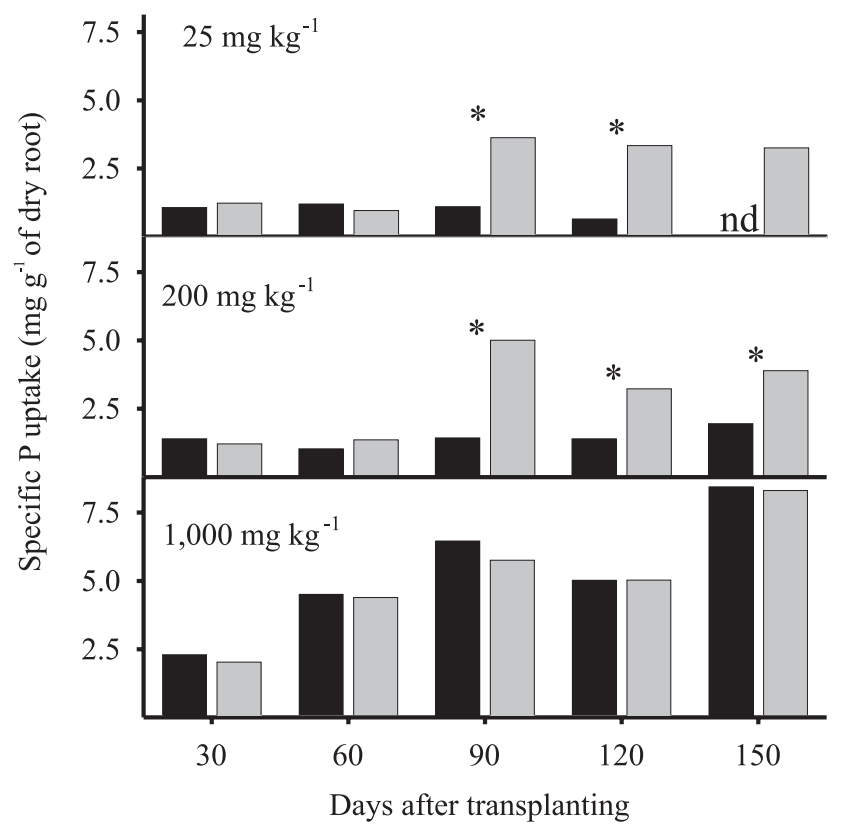

Figure 4. Specific P uptake by Citrus limonia roots, every 30 days after transplanting of + AMF (Glomus intraradices, $\square$ ) and -AMF (Control, $\square$ ) plants, grown with 25,200 or $1,000 \mathrm{mg} \mathrm{kg}^{-1} \mathrm{P}$. Means marked by (*), at each $P$ level and harvest, differ between -AMF and +AMF treatments at $\mathrm{p} \leq 0.05$ (Student's $\mathrm{t}$ test). nd $=$ not determined. for specific $P$ uptake corroborates this statement, since the values for both +AMF and -AMF plants were similar at $1,000 \mathrm{mg} \mathrm{kg}^{-1} \mathrm{P}$.

Seedlings used for rootstock production in Brazil are planted into sterilized substrates in pots, above the soil surface, and are therefore free from mycorrhiza. However, after transplantation to the field, they are normally colonized by native AMF. Future works should evaluate if this period of native mycorrhizal establishment could drive to an initial delay on plant development, in contrast to plants effectively inoculated with mycorrhiza during rootstock formation in the nursery. These investigations should also consider the P status in which the plants are grown.

\section{Conclusions}

1. There is positive response of $C$. limonia to G. intraradices under low soil P availability, while under excessive $\mathrm{P}$ it may be either neutral or negative, depending on the plant developmental stage.

2. High P availability reduces root colonization of C. limonia seedlings by $G$. intraradices, while the external mycelium is not affected.

3. C. limonia roots associated to G. intraradices are more effective in $\mathrm{P}$ uptake under low $\mathrm{P}$ availability in the soil.

\section{Acknowledgements}

To Fapesp, for financial support; to Denise L.C. Mescolotti and Luís F. Baldesin, for their technical support; to Dr. David Henry Moon (Cena/USP), for revising this paper.

\section{References}

ABBOTT, L.K.; ROBSON, A.D.; DE BOER, G. The effect of phosphorus on the formation of hyphae in soil by the vesiculararbuscular mycorrhizal fungus, Glomus fasciculatum. New Phytologist, v.97, p.437-446, 1984.

BETHLENFALVAY, G.; BROWN, M.S.; PACOVSKY, R.S. Parasitic and mutualistic associations between a mycorrhizal fungus and soybean: development of host plant. Phytopathology, v.72, p.889893, 1982.

CARDOSO-FILHO, J.A.; PACOVSKY, R.S.; CARDOSO, E.J.B.N. Growth and metabolic activity of the extramatricial mycelium of endomycorrhizal maize plants. Revista Brasileira de Ciência do Solo, v.23, p.807-815, 1999. 
GIOVANNETTI, M.; MOSSE, B. An evaluation of techniques for measuring vesicular arbuscular mycorrhizal infection in roots. New Phytologist, v.84, p.489-500, 1980.

GRAHAM, J.H. Assessing costs of arbuscular mycorrhizal symbiosis in agroecosystems. In: PODILA, G.P.; DOUDS, D.D. (Ed.). Current advances in Mycorrhizae research. Saint Paul: APS Press, 2000. p.127-140.

GRAHAM, J.H.; DUNCAN, L.W.; EISSENSTAT, D.M. Carbohydrate allocation patterns in citrus genotypes as affected by phosphorus nutrition, mycorrhizal colonization and mycorrhizal dependency. New Phytologist, v.135, p.335-343, 1997.

JIFON, J.L.; GRAHAM, J.H.; DROUILLARD, D.L.; SYVERTSEN, J.P. Growth depression of mycorrhizal Citrus seedlings grown at high phosphorus supply is mitigated by elevated $\mathrm{CO}_{2}$. New Phytologist, v.153, p.133-142, 2002.

KABIR, Z.; O’HALLORAN, I.P.; HAMEL, C. The proliferation of fungal hyphae in soils supporting mycorrhizal and nonmycorrhizal plants. Mycorrhiza, v.6, p.477-480, 1996.

LI, X.L.; GEORGE, E.; MARSCHNER, H. Extension of the phosphorus depletion zone in VA-mycorrhizal white clover in a calcareous soil. Plant and Soil, v.136, p.41-48, 1991.

LINDERMAN, R.G. Vesicular arbuscular mycorrhizae and soil microbial interactions. In: BETHLENFALVAY, G.; LINDERMAN, R.G. (Ed.). Mycorrhizae in sustainable agriculture. Madison: American Society of Agronomy, 1992. p.45-70.

MARSCHNER, H.; DELL, B. Nutrient uptake in mycorrhizal symbiosis. Plant and Soil, v.159, p.89-102, 1994.

MELLONI, R.; CARDOSO, E.J.B.N. Quantification of extraradicular mycelium of arbuscular mycorrhizal fungi on citrus. I. Methods. Revista Brasileira de Ciência do Solo, v.23, p.53-58, 1999a.

MELLONI, R.; CARDOSO, E.J.B.N. Quantification of extraradicular mycelium of arbuscular mycorrhizal fungi on citrus. II. Comparison between different citrus and endophyte species. Revista Brasileira de Ciência do Solo, v.23, p.59-68, 1999b.
MELLONI, R.; NOGUEIRA, M.A.; FREIRE, V.F.; CARDOSO, E.J.B.N. Phosphorus levels and arbuscular mycorrhizal fungi on growth and mineral nutrition of Citrus limonia (L.) Osbeck. Revista Brasileira de Ciência do Solo, v.24, p.767-775, 2000.

MIRANDA, J.C.C.; HARRIS, P.J. The effect of soil phosphorus on the external mycelium growth of arbuscular mycorrhizal fungi during the early stages of mycorrhiza formation. Plant and Soil, v.166, p.271-280, 1994.

MURPHY, J.; RILEY, J.P. A modified single solution method for the determination of phosphate in natural waters. Analytica Chimica Acta, v.27, p.31-36, 1962.

NOGUEIRA, M.A.; CARDOSO, E.J.B.N. External mycelium production by arbuscular mycorrhizal fungi and growth of soybean fertilized with phosphorus. Revista Brasileira de Ciência do Solo, v.24, p.329-338, 2000.

PENG, S.; EISSENSTAT, D.M.; GRAHAM, J.H.; WILLIAMS, K.; HODGE, N.C. Growth depression in citrus at high-phosphorus supply: analysis of carbon costs. Plant Physiology, v.101, p.10631071, 1993.

PHILLIPS, J.M.; HAYMAN, D.S. Improved procedures for clearing roots and staining parasitic and vesicular-arbuscular mycorrhizal fungi for rapid assessment of infection. Transactions of the British Mycological Society, v.55, p.158-161, 1970.

SAS INSTITUTE (Cary, Estados Unidos). SAS version 6.11. Cary, 1996.

SCHUBERT, A.; MARZACHÍ, C.; MAZZITELLI, M.; CRAVERO, M.C.; BONFANTE-FASOLO, P. Development of total and viable extraradical mycelium in the vesicular-arbuscular mycorrhizal fungus Glomus clarum Nicol. \& Schenck. New Phytologist, v.107, p.183-190, 1987.

SYLVIA, D. Activity of external hyphae of vesicular-arbuscular mycorrhizal fungi. Soil Biology and Biochemistry, v.20, p.39-43, 1988.

Received on December 28, 2004 and accepted on May 16, 2005 